The definitive version is available at

http://www3.interscience.wiley.com/journal/118538252/home

(http://onlinelibrary.wiley.com/doi/10.1111/1475-4754.00108/abstract)

DOI: 10.1111/1475-4754.00108

(http://dx.doi.org/10.1111/1475-4754.00108)

\title{
TECHNOLOGY TRANSFER AT THE PERIPHERY OF THE MYCENAEAN WORLD: THE CASES OF MYCENAEAN POTTERY FOUND IN CENTRAL MACEDONIA (GREECE) AND \\ THE PLAIN OF SYBARIS (ITALY)
}

J. Buxeda i Garrigós ${ }^{* 1}$, R.E. Jones ${ }^{2}$, V. Kilikoglou ${ }^{1}$, S.T. Levi ${ }^{3}$, Y. Maniatis ${ }^{1}$, J. Mitchell $^{4}$, L. Vagnetti ${ }^{5}$, K.A. Wardle ${ }^{6}$, S. Andreou ${ }^{7}$

Archaeometry, 45, 263-284 (2003)

\footnotetext{
* Present address: ERAUB, Dept. Prehistòria, Història Antiga i Arqueologia, Universitat de Barcelona, C/ de Baldiri Reixac, s/n, 08028 Barcelona, Catalonia, Spain.
} 
Technology transfer at the periphery of the Mycenaean world: the cases of

Mycenaean pottery found in central Macedonia (Greece) and

the Plain of Sybaris (Italy)

J. Buxeda i Garrigós ${ }^{* 1}$, R.E. Jones ${ }^{2}$, V. Kilikoglou ${ }^{1}$, S.T. Levi ${ }^{3}$, Y. Maniatis ${ }^{1}$, J.

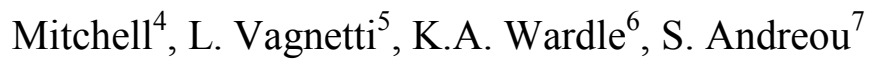

1- Laboratory of Archaeometry, Institute of Materials Science, NCSR 'Demokritos', Aghia Paraskevi, 15310 Attiki, Greece

2- Department of Archaeology, University of Glasgow, Glasgow G12 8QQ, Scotland, United Kingdom

3- Istituto Universitario Suor Orsola Benincasa, Via Suor Orsola, 10, 80135 Napoli, Italy

4- 24 Pound Road, Overton, Hampshire RG25 6ND, England, United Kingdom

5- Istituto di Studi sulle Civiltà dell'Egeo e del Vicino Oriente, CNR, Via G. della Bella, 18, 00162 Roma, Italy

6- Department of Ancient History and Archaeology, The University of Birmingham, Birmingham B15 2TT, England, United Kingdom

7- Department of Archaeology and History of Art, Aristotle University of Thessaloniki, Thessaloniki 54006, Macedonia, Greece

\section{ABSTRACT}

The study of technology transfer in pottery production to the periphery of the Mycenaean world has been addressed by considering two different areas, Southern Italy and Central Macedonia. Technological features such as ceramic paste, decoration and firing, have been determined for different ceramic groups established according to provenance criteria. The studies of technology and provenance have been performed following an archaeometric approach using neutron activation analysis, petrographic analysis, $\mathrm{x}$-ray diffraction and scanning electron microscopy. The results have revealed the existence of two different models. On the one hand, Southern Italy seems to exhibit a more organised pottery production, which follows a Mycenaean-like technology, while in Central Macedonia production is probably more varied, in part based on the technology of the local tradition.

\footnotetext{
* Present address: ERAUB, Dept. Prehistòria, Història Antiga i Arqueologia, Universitat de Barcelona, C/ de Baldiri Reixac, s/n, 08028 Barcelona, Catalonia, Spain.
} 
KEYWORDS: MYCENAEAN POTTERY, SOUTHERN ITALY, CENTRAL

MACEDONIA, NEUTRON ACTIVATION ANALYSIS, OPTICAL

MICROSCOPY, X-RAY DIFFRACTION, SCANNING ELECTRON

MICROSCOPY, FIRING TECHNOLOGY, PIGMENTS

\section{INTRODUCTION}

The interaction of the Mycenaean world with its periphery has long been, and continues to be, an issue of central interest in the archaeology of the second half of the second millennium $\mathrm{BC}$ in the East Mediterranean. The decorated pottery finds have always formed the crucial evidence pointing to the date and nature of Mycenaean contact with the 'periphery'. To the east and south of the Aegean, that is Cyprus, the Levant and Egypt, the traditional area of study, the combination of analysis of stylistic attributes and chemical characterisation has made substantial progress in identifying the status of the Mycenaean pottery as 'local imitation' or 'import' (Jones 1986, 542f; Mommsen et al. 1992). The scope of this enquiry can be extended to consider technique and tradition as well; Leonard et al.'s (1993) combination of Instrumental Neutron Activation Analysis (INAA) and xeroradiography on Mycenaean stirrup jars is a good example of such an approach.

During the last two decades, attention has shifted more towards Mycenaean contact with the west, that is with Italy and associated islands, and the north, principally Greek Macedonia. As a result of study of the pottery finds from these areas, and again supported by programmes of analysis, a secure picture of the process of acculturation has been built up. Whereas the Mycenaean pottery of the Shaft Grave period $\left(17^{\text {th }}-16^{\text {th }}\right.$ c. BC) found in small quantities at trading settlements in Italy (such as Vivara and the Aeolian Islands) and, for instance at Torone in the Chalkidiki in Macedonia, was in all likelihood imported from southern Greece, the status of the subsequent LH III decorated pottery has a marked chronological basis to it: as acculturation progressed during the $13^{\text {th }}$ and $12^{\text {th }}$ c. BC, so the amount of 'local' Mycenaean increased. The reader is referred to Vagnetti (1999), and Wardle (1993) and Andreou et al. (2001) respectively for the most recent accounts of the two areas. The marked technological contrast between the indigenous pottery belonging to the hand-made tradition and the kiln-fired wheel-made pottery of the Mycenaean world, technology that will be adopted in these areas, is fundamental to the discussion of the acculturation process. 
This paper describes our investigation into the nature of the supposed local Mycenaean pottery in two peripheral areas, central Macedonia and southern Italy. The following questions arise: does this pottery represent centralised production in the two areas, or were there several locations of production? How readily available were suitable raw materials for building the vessels and for its silicate-based glossy decoration? What firing regimes would have been in place? What can be said about technology transfer from the Mycenaean world to its periphery? In tackling these questions, one of our aims has been to achieve a more balanced 'archaeometric' view of Mycenaean pottery which until now has been over-concerned with questions of origin to the detriment of technological issues.

The investigation is based primarily on material from two sites which have already received archaeometric attention: Assiros Toumba in Macedonia (northern Greece), and Broglio di Trebisacce in the Plain of Sybaris (southern Italy). The earlier work at these two sites is outlined below. In addition, smaller numbers of individual samples were considered from three other sites in Macedonia - Chrysavgi, Aghios Mamas and Toumba Thessaloniki - and one further site in the Plain of Sybaris, Rosa Russa (Figure 1). The first part of this paper concerns understanding better the different Mycenaean pottery types established in Macedonia on archaeological grounds, while the second one mainly concerns the understanding of technology transfer in Southern Italy.

\section{ANALYTICAL METHODS}

Chemical characterisation was carried out by INAA for 21 elements (Sm, Lu, U, Yb, As, Sb, Ca, Na, La, Ce, Th, Cr, Hf, Cs, Tb, Sc, Rb, Fe, Ta, Co and Eu) at the NCSR 'Demokritos' swimming pool reactor (Hein et al. 2002). Before data processing consisting of Principal Components Analysis (PCA) and cluster analysis (the former with routine $4 \mathrm{M}$ of the BMDP package and the latter with Clustan), the data were normalised according to the Sc content and log transformed (Aitchison 1986; Buxeda 1999). The comparability of INAA databases for the Aegean is known to have been achieved between those generated respectively at NCSR 'Demokritos', Berkeley (Asaro-Perlman database, re-evaluated by French et al. (forthcoming) and Tomlinson $(1997$; 1998) for sites throughout the Peloponnese, Perati in Attica and Thebes and Gla in Boeotia), Bonn (Mommsen et al. 1988; 1994: for Argolid and Achaia; Hein et 
al. 2002) and Manchester (Tomlinson 1997 (for Peloponnese); 1998 (for Gla); 2000 (for Boeotia)).

Petrographic analysis consisted of examination of thin sections of the pottery. The degree of sorting of inclusions and the varying proportions of inclusion size were the main factors in guiding the petrographic classification.

For the technological aspect of the study, Scanning Electron Microscopy (SEM) and X-Ray Diffraction (XRD) were employed. A fresh fracture, transverse to the wall and in a direction parallel to the vertical dimension of the vessel, was obtained from each sample and examined under the SEM (Kilikoglou 1994). XRD diffractograms were obtained by the powder method, using a Siemens D-500 diffractometer (Buxeda et al. 2001). Some experiments were also conduced on raw clays, fired as briquettes at 800 and $950^{\circ} \mathrm{C}$ in oxidising atmosphere at a heating rate of $200^{\circ} \mathrm{C} / \mathrm{h}$ and maintaining the peak temperature for 1 hour.

\section{RESULTS}

Macedonia

To date, only two studies have tackled chemically the issue of Mycenaean pottery production in Macedonia, both of them based on material excavated in the 1970s at Assiros Toumba, in the Langadas Basin, and nearby Chrysavgi (from where several individuals classed archaeologically as Local Mycenaean type -CLM- were taken), (Jones 1986: 108, 494; using optical emission spectroscopy (OES)), and at Kastanas (Mommsen et al. 1989; using INAA), on the River Axios. In both cases, the archaeological criteria of date, style and fabric were used to provide the initial classification of the pottery, and they both used the indigenous hand-made Brown Burnished (BB) ware as local reference material. At Assiros, which concerns us in the present study, the Mycenaean-type pottery was divided into Local (Assiros Local Mycenaean, ALM), Provincial (APM) and Imported (AIM) (Wardle 1980; 1993). These terms Local, Provincial and Imported are based on practical visual distinctions applied to a broad spectrum of material found at Assiros in the first instance. At one end, Local was defined as a distinctive ware having (usually) a poorly fired pink fabric with a grey core, and often a slightly porous surface; the quantity of this category indicated that, other things being equal, it was probably made in the vicinity 
of Assiros. At the other end of the spectrum was a small quantity of Imported, of LH IIIA-B date, defined as pottery of outstanding quality, usually with a lustrous surface and glossy paint of the kind which would have passed without remark at Mycenae or many other southern Greek sites. In the present state of our knowledge this quality of pottery was only made outside Macedonia, perhaps in Thessaly or further south. This class was never common at Assiros and became rarer with the passage of time (Figure 2). All the rest of the Mycenaean pottery was defined as Provincial, and included a wide range of clay colours and fabrics which seemed to have come from a variety of sources, some of which may have been local to Assiros while the rest seemed likely from the quantity to have been made in other parts of Macedonia, perhaps on the coast. Almost all were uniformly fired, usually with a buff or reddish core but a dull surface. The later Mycenaean pottery, of LH IIIB and C date, belonged in the main to the Local and Provincial classes (Figure 2). The archaeometric results so far have shown the existence of local production in the Langadas Basin, and furthermore revealed that the distinction between Provincial - mostly associated with the Chalkidiki (Aghios Mamas area) - and Imported Mycenaean - not uniform but some of it being tentatively linked to Thessaly (Jones 1986: 112) - was not clear cut. At Kastanas, where the Mycenaean pottery was archaeologically divided in Local and Imported (Hänsel 1989), the results revealed twelve groups consistent with regional but perhaps not local production, including one group (G1) to which some sherds from Mesimeri and Thessaloniki belong (Mommsen and Maran 2000-2001), as well as some imports from further afield, including three linked to the Argolid. Moreover, as regards other relevant chemical data for central Macedonia, there are data sets obtained by atomic absorption spectrometry (AAS) for ProtoGeometric pottery from Mende (Kessisoglou et al. 1996) and Torone (Whitbread and Jones, forthcoming), and by OES for Byzantine pottery from Thessaloniki (Megaw and Jones 1983).

The samples selected for the present study, which are listed in Table 1, include some from Assiros and all those from Chrysavgi that had been previously analysed but with the addition of more examples from Assiros of the three classes of Mycenaean. A selection of samples from the excavations at Toumba, Thessaloniki (Andreou and Kotsakis 1999) belonging to the Matt-painted (TMA) and Mycenaean (TMY) types was also included that would complement those of hand-made pottery whose petrographic composition and firing temperature range have been determined by Kiriatzi et al. (1997). The Mycenaean from Toumba and Aghios Mamas (AM), the latter excavated by Heurtley (1939) and included here for petrographic analysis, were 
not archaeologically divided into local, provincial or imported groups, but just considered as Mycenaean. Finally, a group of decorated LH IIIB sherds from Mycenae were analysed for comparative technological purposes.

Chemical and petrographic data Classification by PCA using the covariance matrix of the INAA data (using the elements Sm, Lu, U, Yb, Na, La, Ce, Th, Cr, Hf, Cs, Rb, $\mathrm{Fe}$, Ta, Co, and Eu, normalised to Sc and log transformed) for all 106 individuals from Macedonia with no rotation of axis revealed that two samples classified as outliers (APM104 and TMA16) presented extreme values in the first principal components (PCs), due to their high $\mathrm{Cr}$ and Co contents. Also, a group of five individuals (classified as chemical group Local Mycenaean 5 - LM5 -, and basically related to Toumba Thessaloniki) were far from all other individuals, having high positive values in the second principal component, due to their high values in Cs. This situation was forcing all other individuals to a cloud of points close to the origin of the axis. On their removal and repeating PCA, the resulting plot of the first two PCs is as shown in Figure 3. PC1 and 2, accounting together for $73 \%$ of the total variance, are dominated by $\mathrm{Cr}$ and $\mathrm{Co}$, and by $\mathrm{Cr}, \mathrm{Hf}, \mathrm{Na}$ and $\mathrm{Co}$ contents respectively. A broad spectrum of compositions is immediately evident, and both calcareous and low calcium compositions are represented, yet the following general trends can be discerned (Tables 2 and 3): (1) Assiros Brown Burnished ware forms two (chemically similar) groups (chemical groups Brown Burnished - BB1 and BB2), which are distinguishable from, (2) mostly Local Mycenaean (chemical groups $L M$ ) from Assiros (LM1 to LM3), having negative PC2 scores, and Chrysavgi (LM4), close to LM2, and (3) Provincial and Imported Mycenaean from Assiros and Mycenaean from Thessaloniki (chemical groups Probable Imports - PII to PI3) with positive PC2 scores. It is also possible to isolate more discrete groupings of samples sharing similar compositions, as shown in Figure 3, but many samples are left unassigned.

The provenance of Brown Burnished and Local Mycenaean can be explored by turning now to the petrographic classification in Table 4 (Mitchell 1993). As can be seen, inclusion types are generally metamorphic with lesser amounts of igneous material in such a way that the variation in the composition type is less significant than the variation in texture - the inclusion size range and frequency. This picture harmonises with the sedimentary geology of the Langadas Basin and the Neogene sedimentation close to Aghios Mamas. Therefore, the geological compatibility between the chemical BB1-2 and LM1-4 groups and the geology of the Langadas 
Basin is consistent with a local origin to the Langadas Basin. Even so, the correlation between the chemical and petrographic classifications is uneven (Figure 3): LM1 comprises mainly Petrographic Group (PG) 2, LM2 is less uniform but contains four examples of Petrographic Group 5, LM4 is petrographically very heterogeneous (Petrographic Groups 1, 2, 3, 4, 5 and unassigned), LM3 is a mix mainly of Petrographic Groups 3 and 4. Finally, $B B 1$ and $B B 2$ are made up of Petrographic Group 1 (Brown Burnished). Two superimposed effects are observed here. On the one hand, the Langadas Basin and other parts of Central Macedonia lie in a region, metamorphic in geological character, whose clays have a significant natural variation both chemically and petrographically. As a consequence, while chemical groupings can be identified, a quarter of the samples analysed are unassigned. Furthermore, chemical differences may not manifest themselves petrographically and vice versa, an example being Petrographic Group 5 with an igneous character which does not stand apart chemically.

The comparison with chemical databases for Kastanas and other sites in Macedonia shows that the one local/regional group chemically defined by Mommsen and Maran (2000-2001) at Kastanas emphatically does not match either LM1-5 or PII and PI2, and the same seems to apply to some of the groups from Mende and Torone. Only the group of Byzantine pottery (and modern brick) from Thessaloniki offers rough similarity. This comparison enables us to propose that groups PII and PI2 are for the present regarded as products of Central Macedonia but from different centre(s) from those of $L M$, while group LM5 does not appear to be consistent with an origin in either Thessaloniki or elsewhere in Central Macedonia. Finally, chemical group PI3 does not show similarities with Kastanas, and looking further afield, coastal Thessaly also looks unlikely, the Argolid is very unlikely, and yet there is some similarity with some of the available data for central Greece, such as Thebes or better Gla. Regarding the two Matt painted individuals from Thessaloniki, both of them have dissimilar compositions: one is probably local (TMA15), the other (TMA16) remains ungrouped and cannot be classified, having anomalous $\mathrm{Th}$ and $\mathrm{Rb}$ contents. In any case, as a first result, it is clear that the archaeological Local, Provincial and Imported classification based to a large extent on fabric and decorative quality is not fully upheld chemically.

Technological characterization The technological study was conducted on each chemical group in turn. The results in Table 2 summarise the general trend of each 
group. The firing temperatures were estimated after combining SEM examination with the results obtained by XRD. A clear division is observed in the calcium content of the clays used, and yet no correlation can be established between the calcium content and the firing temperatures estimated. Thus, there are low calcareous groups both with low firing temperatures (LM2 and LM4) and high ones (LM1 and LM3), as well as calcareous groups with low (LM5) and high firing temperatures (PI1, PI2 and PI3). Table 2 includes the estimated firing temperatures for the comparative samples from Mycenae.

An important observation is that all the low calcareous groups fired at high temperatures exhibit a special microstructure that can be exemplified with ALM111. As may be observed macroscopically, the pottery archaeologically classified as Local Mycenaean has a wide, dark grey core sandwiched between two brownish-red layers. This observation extends to the microstructure: the outer areas exhibit (Figure 4 top) a typical microstructure of continuous vitrification in low calcareous clays, while the core (Figure 4 bottom) has a completely different microstructure. Here, the microstructure consists of a continuously vitrified surface containing a high concentration of fine bloating pores, with a small diameter typically below $5 \mu \mathrm{m}$. This kind of microstructure is typically produced by a fast firing (Maniatis and Tite 1975) and is observed basically in groups $L M 1$ and $L M 3$. This observation raises the question of the nature of the firing structure. Taking the term kiln to denote a structure in which the pottery is separated from the fuel (in a firing chamber), it is proposed that fast firing is consistent with the use of a structure other than a kiln; such a structure could be a bonfire or a pit, but in both cases the implication is that fuel and pots are in contact with each other. Significantly, Kiriatzi et al. (1997) also infer fast, non-kiln firing from their SEM analysis of hand-made pottery from Toumba. It is well established that kiln firing provides a more controlled firing of longer duration and slower heating rates (Gosselain 1992; Kingery 1997).

The study with SEM-EDX of the red and black colours used to decorate Mycenaean pottery clearly indicated the general use of very fine grain size, illitic-rich clays, both in the case of low calcareous and calcareous clays. Only in the two Matt painted samples oxides were employed (iron oxides for red in TMA15 and manganese oxides for black in TMA16). Also evident was the higher quality of decoration in chemical groups $P I 1, P I 2$ and $P I 3$, which was inferred especially from the $\mathrm{K}_{2} \mathrm{O}$ and $\mathrm{Fe}_{2} \mathrm{O}_{3}$ contents of the paint. Drawing in the data for Mycenae, the range of the former element was $3-5 \%$ in the body, rising to $5-11 \%$ range in the chemical PI groups 
paints, $9-11 \%$ at Mycenae, and $4-7 \%$ in the chemical $L M$ groups paints; the corresponding ranges for iron were $6-14 \%$ in the body and $12-18 \%, 12-14 \%$ and 8 $12 \%$ in the paints respectively. Moreover, the creation of a well-sintered paint layer was also dependent on the firing temperatures achieved. Thus, the best results are to be found in chemical groups LMI and LM3 for low calcareous clays, and chemical groups $P I 1, P I 2$ and $P I 3$ for calcareous ones.

The above results provide important evidence related to the use of black decoration in the Mycenaean-type pottery. The technique adopted was the same as that found elsewhere in the Mycenaean world, that is the iron reduction technique; there were no examples of carbon black or manganese oxide based paints. As regards the final colour, red or black, this was achieved through control of the firing atmosphere: the red was produced by a typical reducing-oxidising firing and oxidising cooling $(\mathrm{RO} / \mathrm{O})$, while the black was produced by the same $\mathrm{RO} / \mathrm{O}$ firing but introducing a short period of reduction at the beginning of the cooling period. It is important to note that the black decoration is related to the calcareous groups, which are probably imported. In these calcareous groups, high quality black decoration can be observed, especially in chemical group PI3 such as in Figure 5. By contrast, low calcareous chemical groups LMI to LM4 present a total absence of black decoration, only red colours being observed. This could also be explained by the absence of kiln structures, as already suggested by the use of fast firing. In this case, the use of a bonfire in an open firing would make the necessary control of the firing atmosphere impossible. In such a situation, a red colour would be the natural product of a $\mathrm{RO} / \mathrm{O}$ firing.

Southern Italy

During the Middle Bronze Age (17 $7^{\text {th }}$ century BC), a settlement system in the Plain of Sybaris in Northern Calabria developed, and it continued for a millennium until the Greek colonization of the Plain at the end of the $8^{\text {th }}$ century BC. About thirty sites have been found, some investigated with excavation, others only by survey. Among them, Broglio di Trebisacce in Northern Calabria is a typical 'major site', situated on a Quaternary terrace and overlooking the sea and the Plain of Sybaris, with a remarkable continuity of settlement from the Middle Bronze Age to the Early Iron Age. Discovered in 1978, the site has been excavated continuously since 1979 by the Soprintendenza Archeologica della Calabria and the University of Rome 'La 
Sapienza' (Peroni and Trucco 1994; Peroni and Vanzetti 1998; Levi et al. 1998; Levi 1999; Peroni 2000; Bettelli 2002). By contrast, Rosa Russa is a 'minor' site on a small terrace investigated only by survey, occupied during the Middle Bronze Age and abandoned during the Recent Bronze Age (Bergonzi et al. 1982, 168-718; Peroni and Trucco 1994, 776-778).

At Broglio, the first occurrence of Mycenaean sherds (also called Aegean type regardless of their imported or local provenance) and possibly the local wheel-made Grey ware appears in some Middle Bronze Age 3 layers (equivalent to Aegean LH IIIA). The Central Hut had a high density of such wares during the Recent Bronze Age (equivalent to LH IIIB-early IIIC), and to this period the production of Aegeanderived storage jars (dolia), associated with the introduction of olive cultivation, began. The Final Bronze Age (equivalent to LH IIIC middle-late) saw an increase in building activities (also with the defensive wall and ditch) and an accumulation of goods and crucial economic activities on the acropolis (storage-rooms, iron working). The defences of the acropolis complete the picture. The settlement pattern of the Plain of Sybaris suggests that the Final Bronze Age was a period of intensive territorial competition, and the importance of the acropolis at Broglio points to a precise role of local élite groups in directing this phenomenon.

The Plain of Sybaris has been the focus of large-scale and long-term laboratory-based study of Mycenaean-type and indigenous pottery of the Late Bronze Age. It has been shown by chemical means that the large majority of the decorated Mycenaean-type pottery found at Broglio di Trebisacce was made within the Plain, if not at Broglio itself (Jones et al. 2002). Other pottery classes of Mycenaean derivation - Grey ware and the storage jar (dolium) - together with a later adaptation of decorated Mycenaean - Figulina, that appears in the Final Bronze Age-Early Iron Age and was slipped and decorated with red and black painted designs - were also produced there. Moreover, evidence of production of the indigenous handmade Impasto and the more specialised product, the dolium, as well as their circulation within the Plain has been decisively obtained by petrography and other means (Levi 1999). Owing to the existing chemical database for the Plain, it was decided to restrict further chemical characterisation to a small sample set and to use the resulting data in part as an inter-laboratory comparative exercise, the results of which have been reported elsewhere (Jones et al. 2002). On the technological front, the results presented here complement those of Levi (1999, 332-34) on the dolia and Impasto using XRD and radiography. 
For the present study, 53 samples from Broglio di Trebisacce and 4 samples from Rosa Russa were analysed by the techniques shown in Table 1. The sampling covered all the pottery fabrics identified macroscopically in the area and dating to the Middle, Recent and Final Bronze Age and the Early Iron Age. The 13 Aegean-type sherds (labelled BTA) belong to wheel-made closed vessels, in some of which traces of painted decoration are preserved. In particular BTA1-2, 4 and 5 correspond to a widenecked amphora with horizontal handles - very frequent in the Late Bronze Age layers at Broglio, having close parallels in Late Minoan III Western Crete (Vagnetti in Peroni and Trucco 1994, 402-3, 407) - and BTA3 belongs to a closed vessel of medium size, with a high cylindrical neck, whose surface is completely covered by black paint. All Figulina ware (labelled BTF) samples are closed vessels, whose surface is very often decorated with geometric matt-painted patterns, sometimes wheel-made, but more often handmade (Buffa in Peroni and Trucco 1994). The Grey wheel-made ware (labelled BTG) is a fabric particularly common in the Sibaritide in the local LBA. The treatment of clay and the use of the wheel are clearly of Aegean derivation, while the shape repertoire is still more linked to the local tradition (Belardelli in Peroni and Trucco 1994; Bettelli 2002). Sometimes this particular fabric is decorated with a darker grey painting (BTG27-28, BTG64). The samples of dolia (labelled BTD) represent well the fabric variability within this class of vessels (Tenaglia in Peroni and Trucco 1994; Tabò in Peroni and Vanzetti 1998). Impasto pottery, representing the local handmade burnished potting tradition, is represented both by samples from Broglio and Rosa Russa. Moreover, three miscellaneous ceramic materials found at Broglio (BT1026, daub; BT2005, fornello; BT2006, oven lining) were also examined.

Additionally, the firing properties and textural features of thirteen modern clays collected from locations around the Plain of Sybaris were examined as experimental briquettes fired at 800 and $950^{\circ} \mathrm{C}$; those from Trebisacce and Marzuca close to the site and Avena and Corigliano (locations in Levi 1999: Fig. 23-24) were also examined by XRD and SEM.

Characterisation and technological data Classification by cluster analysis of the chemical data (using the elements $\mathrm{Sm}, \mathrm{U}, \mathrm{Yb}, \mathrm{Na}, \mathrm{La}, \mathrm{Th}, \mathrm{Cr}, \mathrm{Hf}, \mathrm{Cs}$, and Fe, normalised to Sc and log tranformed) for 30 pottery samples indicated the presence of one large group, $A 1$, and one smaller related group, $A 2$, with 18 and 3 samples 
respectively, two other small groups, $B$ and $C$, and outliers (Table 5). Chemical groups $A 1$ (Table 3 ) and $A 2$ both have calcareous compositions with the exception of two Impasto samples. On the basis of comparison with previously obtained chemical data for these classes (set out in full in Levi 1999: 76f), they are likely to be products of the Plain, if not Broglio itself. They comprise most of the decorated Mycenaean type, Grey and Figulina examples, and, furthermore, they separate clearly from a small group of non-calcareous Impasto (chemical group $C$ ), another small group of two dolia (chemical group $B$ ) and other four outliers. Among the outliers are two Mycenaean-type examples, BTA3 and BTA68, one Figulina and one Impasto. The former are imports to the Plain, BTA3 from an as yet undetermined source probably in the Aegean; BTA68 is from a different source.

A closer look at the technological parameters estimated for the decorated Mycenaeantype and Figulina (Table 5) reveals that the firing temperature for the group of the Plain ranges from very low firing temperatures, exhibiting a typical microstructure with no vitrification (NV), and showing in some cases calcareous fossils, which indicates temperatures below $750 / 800^{\circ} \mathrm{C}$ (Kilikoglou 1994), to high firing-overfiring temperatures, exhibiting a microstructure of a total vitrification (TV) stage which indicates temperatures over $1080^{\circ} \mathrm{C}$, the atmosphere being usually $\mathrm{RO} / \mathrm{O}$. On the other hand, the likely Aegean imports, BTA3 and BTA68, the latter associated to BTA16 on macroscopic grounds, exhibit always high firing temperatures. All these data show that the proposed products of the Plain have a wide range of firing temperatures, indicating that control over their firing was not as good as that on the likely imports. Moreover, this also differentiates the Mycenaean at Broglio from the Mycenae reference group, because the latter is with one exception uniformly fired in the range $950-1050^{\circ} \mathrm{C}$ (Table 2). Turning to the decoration, the red and black decoration, of imports but also of products of the Plain, represents the finer fraction of an illitic clay, and in this respect it is very similar to the corresponding decoration on pottery from Mycenae, and thus of better quality than that of the chemical $L M$ groups from Macedonia (Table 2). The white slip on the two likely imports, BTA68 and BTA16, was found to be rich in $\mathrm{Si}, \mathrm{Al}$ (c. 10\% more in the slip than in the body) and $\mathrm{Ca}$, with smaller amounts of $\mathrm{Fe}$ and $\mathrm{Mg}$. The microstructure of this slip shows clearly that it had been applied before firing, and that it had started to sinter but did not have the characteristic smooth surface expected in well vitrified materials (Figure 6, top). It is possibly a lime silicate white, as observed on some Aegean Bronze Age pottery (Noll 1982; Jones 1986: Table 9.8a). 
In relation to the Grey ware, all the samples analysed by INAA are products of the Plain, unpainted with firing temperature ranging from $\mathrm{NV}$ to $\mathrm{Vc}+$ stages. The firing was always reducing but in some cases a darker core could be observed (indicated with asterisk in Table 5). The surface treatment was restricted to polishing/burnishing, there being no slip. BTG24, BTG67 and BTG25, which are the high fired individuals, exhibit a characteristic shiny metallic grey colour which is attributed here to the effect of high firing temperatures. This effect is well known in calcareous clays fired under reducing conditions at high temperatures, for instance in the technological recipe of Aegean Minyan Ware (Jones 1986: 788f). By contrast, BTG27 and BTG28 (not analysed chemically) stand apart by virtue of the presence of black decoration and very high firing temperature (Figure 6 bottom), but whether these two features are related cannot be established on the basis of only two examples. In any case, the decoration is suggestive of the use of the finer fraction of an illitic clay, in common with the examples of other wares in Table 5.

The dolia exhibit a range of chemical compositions which are consistent with the use of a fine calcareous clay containing differing types and amounts of tempering material. The latter material ranges from sandstone and calcite, calcareous siltstone to crystalline rocks and mica, as already shown from petrographic analysis (Levi 1999: 145; Jones et al. 2002). The dolia belonging to chemical groups $A 1$ and $A 2$ also exhibit a wide range of firing temperatures, spanning NV to Vc. On the other hand, the two dolia in chemical group $B$ are more consistent in their firing.

Finally, the results clearly demonstrate the contrast in technology between all the previous Aegean-influenced wares and Impasto. The latter has a low calcium content and contains a variety of materials (Impasto sample BTI59, found at Rosa Russa, is rich in garnet and mica; chemical group $C$, found at Broglio, sandstone, siltstone, calcite; chemical group A1, found at Broglio, mainly siltstone). It is fired at low temperatures, developing a soft structure that corresponds to a completely different technological tradition from the well fired Aegean products, which typically exhibit extensive vitrification. Its surfaces were burnished but not slipped. These characteristics apply even to the two samples whose compositions apart from their $\mathrm{Ca}$ contents, were ascribed to the $A 1$ group. Moreover, since all the clays included in the present study were found to be calcareous (17.8-18.6\% $\mathrm{CaO}$ range) and not themselves compatible sources for the Impasto products; instead it is possible Impasto 
was made of a clay/soil mix. Two of the miscellaneous ceramic materials, BT1026 (daub) and BT2006 (oven lining), were calcareous, 19 and 22\% CaO respectively, while BT2005 (fornello) was akin chemically to Impasto.

\section{DISCUSSION}

While the indigenous pottery of the two regions, Impasto and Brown Burnished ware, share common traits, such as the use of low calcareous clays, fired at low temperatures, decorated only by burnishing/polishing the surface, the present study has provided evidence that the Mycenaean/Aegean influence has acted in different ways in both regions.

The technology of production has been revealed to be more controlled in southern Italy than in Central Macedonia. In the former, the results of this study have, independently of the archaeological picture, indicated that potters, either Mycenaean or at least familiar with the Mycenaean tradition, were successfully producing pottery in an Aegean-influenced manner. In that sense, Mycenaean type and Aegeaninfluenced classes were produced, by using the wheel and calcareous clays, fired in kiln structures, and, although the firing temperature is wide, it is the relatively high proportion of the pottery that was fired typically at temperatures in the range 850$950^{\circ} \mathrm{C}$ that is impressive. Nevertheless, the ability to produce black decoration indicates knowledge of kiln firing and the ability to control the changes of oxidisingreducing-oxidising episodes during firing. In this case, the dichotomy between Mycenaean and indigenous traditions is more clear cut than in central Macedonia where by contrast a wide diversity of technological recipes (affecting the calcium content in the clays used), firing temperatures, duration of firing, decoration, and even the use or otherwise of kiln structures is observed. This diversity is not random but is supported by the clear correlation between chemical groups and technology used, suggesting the co-existence of different traditions that may have been in operation. Thus, some chemical groups representing local/regional production (LM1-4 groups), in which the Mycenaean influence seems to be restricted more to style than to technology, were made from low calcareous clays even though better quality calcareous clays were available in the region and indeed were sometimes exploited. These products were not fired in a kiln, giving little control of firing atmosphere with the result that only red decoration was achieved. These firing structures could be pitkilns, perhaps like those of Early Bronze Age date reported from Aghios Mamas 
(Heurtley 1939: 5-7) and Polychrono (Pappa 1990) in the Chalkidiki and Sindos

(Andreou 1996-97) near Thessaloniki. By contrast, true kilns have not yet been found in the north, the nearest ones of Mycenaean date being found at Velestino (BatziouEfstathiou 1994) and Dimini (Adrimi-Sismani 1999) in Thessaly. Thus, the normally strict contrast between Mycenaean from calcareous clays and fired at high temperature, and handmade pottery, built from low calcareous clays and fired at low temperatures, is an over-simplification, restricted perhaps to the Mycenaean heartland, and some other areas like southern Italy.

Accepting that our two case studies are different in size, the two regions also present contrasting pictures as regards the primary materials. In Central Macedonia many fabrics are observed; there seems to be little standardisation which we believe to be the result of two superimposed phenomena, one geological - the clays in the region tend to have a broad continuous spectrum of compositions - and one archaeological several possibly small workshops using different recipes rather than centralised production of Mycenaean pottery. The link found between several groups and sites (chemical groups LM1-3 with Assiros; LM4 with Chrysavgi), as well as the picture offered by the research conducted at Kastanas, seems to support the interpretation of dispersed production in this region. It is significant that the chemical evidence for imports from outside Macedonia is slim even for the three chemical groups, PI1-PI3, that share the features of calcareous clays and high firing temperatures with black and red decorations achieved usually from a well controlled kiln atmosphere. Especially for these groups, as well as for LM5, its status awaits further evaluation as the database for Macedonia expands, in the first instance in the light of results from Toumba, Thessaloniki for which INAA analyses of more examples of Mycenaean are expected to be completed in 2002. In the meantime, the terms Local, Provincial and Imported Mycenaean remain useful archaeological concepts in the Langadas Basin even if they do not accurately reflect the true situation in terms of provenance alone. By contrast, the position in the Plain of Sybaris is somewhat clearer due in the part to the larger chemical database than for central Macedonia. The chemical data for decorated Mycenaean are consistent with discrete production within the Plain, a result that seems to be paralleled elsewhere in southern Italy, for instance in the Metapontum (Termitito) and Taranto areas (Jones et al. 2002). It is logical to suppose there were potters working in the Mycenaean tradition either permanently based in these areas or less likely itinerant; in any case, however their operations were organised, their output had a good measure of standardisation. 
Before concluding, it is important to point that, at the methodological level, this investigation has shown the merits of combining provenance with technological enquiry, the latter achieving its main impact when linked to a well-established chemical group. Returning to the questions posed at the outset of this paper, we have made progress in describing the situation and establishing that a new technology had arrived in the two regions, but we have not explained the technology transfer. For Macedonia, this will require a larger database for Mycenaean pottery in regions such as Thessaly, as well as a fuller archaeological picture with regard to production, information that is in any case going to be hard to come by. There will be no quick solutions.

\section{ACKNOWLEDGEMENTS}

This investigation was carried out with the support of the EC Human Capital and Mobility Program (CHRX-CT94-0615) which is gratefully acknowledged.

Petrographic analysis of Macedonian samples (by J. Mitchell) was carried out in the Fitch Laboratory, British School at Athens; we thank Dr. I.K. Whitbread for discussion of its results. We are grateful to Prof. H. Mommsen and Prof. J. Maran for permission to read their paper in advance of publication. R. Peroni, A. Vanzetti, E. Lattanzi and S. Luppino are thanked for facilitating the work in Calabria.

\section{LIST OF ABBREVIATIONS}

Related to analytical and statistical Techniques: AAS - Atomic Absorption Spectrometry; EDX - Energy Dispersive X-ray fluorescence; INAA - Instrumental Neutron Activation Analysis; OES - Optical Emission Spectroscopy; PC - Principal Component; PCA - Principal Component Analysis; SEM - Scanning Electron Microscopy; XRD - X-Ray Diffraction.

Analytical groups: LM - Local Mycenaean (Macedonia); PI - Probable Imports (Macedonia); $B B$ - Brown Burnished (Macedonia); PG - Petrographic Group (Macedonia); A1 and A2 Mycenaean-type pottery in the Plain of Sybaris.

Firing atmosphere: O - oxidising; R - reducing; RO/O - Reducing-oxidising firing, oxidising cooling. 
Vitrification stage (firing temperature): NV, no vitrification; IV, initial vitrification; $\mathrm{Vc}$, extensive vitrification (Vc- initial; Vc+ advanced); TV, total vitrification.

\section{REFERENCES}

Adrimi-Sismani, V., 1999, Mykinaikos kerameikos klivanos sto Dimini, in Proceedings of the International Conference "The periphery of the Mycenaean World" (Lamia 1994) (ed. Ph. Dakoronia), 131-42, Lamia (in Greek).

Aitchison, J., 1986, The Statistical Analysis of Compositional Data, Chapman and Hall, London.

Andreou, S., 1996-97, Sindos: apothetis keramikis tis proimis epochis tou Chalkou, Archaiologikon Deltion, 51-52 A, 51-84 (in Greek).

Andreou, S., and Kotsakis, K., 1999, Mykinaiki parousia? Mykinaiki peripheria? I

Toumba Thessalonikis, mia thesi tis Epochis tou Chalkou sti Makedonia, in Proceedings of the International Conference "The periphery of the Mycenaean World” (Lamia 1994) (ed. Ph. Dakoronia), 107-16, Lamia (in Greek).

Andreou, S., Fotiadis, M., and Kotsakis, K., 2001, The Neolithic and Bronze Age of Northern Greece, in Aegean Prehistory: A Review (ed. T. Cullen), American Journal of Archaeology (Supplement 1), Boston.

Batziou-Efstathiou, A., 1994, Mykinaikos kerameikos klivanos, in Thessaly, Fifteen Years of Archaeological Investigation, 1975-1990. Proceedings of an International Conference at Lyon, 17-22 April 1990, 215-24, The Hellenic Ministry of Culture, Athens (in Greek).

Bergonzi, G., Buffa, V., Cardarelli, A., Giardino, C., Peroni, R., and Vagnetti, L., 1982, Ricerche sulla protostoria della Sibaritide, 2, Cahiers du Centre Jean Bérard, VIII, Napoli.

Bettelli, M., 2002, Italia meridionale e mondo miceneo. Ricerche su dinamiche di acculturazione e aspetti archeologici, con particolare riferimento ai versanti 
adriatico e jonico della penisola italiana, Grandi Contesti e Problemi della Protostoria Italiana, All'Insegna del Giglio, Firenze.

Buxeda i Garrigós, J., 1999, Alteration and Contamination of Archaeological Ceramics: The Perturbation Problem, Journal of Archaeological Science, 26, 295313.

Buxeda i Garrigós, J., Kilikoglou, V., and Day, P.M., 2001, Chemical and mineralogical alteration of ceramics from a Late Bronze Age kiln at Kommos, Crete: the effect on the formation of a reference group, Archaeometry, 43, 349-71.

French, E.B., Hoffmann, S.M.A., and Robinson, V.J., forthcoming, The Perlman and Asaro Analyses of the Hagios Stephanos Sherds: A Statistical Re-Evaluation, in Excavations at Ayios Stephanos in Laconia (ed. R. Jenko), Annual of the British School at Athens, Supplementary Volume Series, Athens.

Gosselain, O.P., 1992, Bonfire of the Enquires. Pottery Firing Temperatures in Archaeoogy: What for?, Journal of Archaeological Science, 19, 243-59.

Hänsel, B., 1989, Kastanas. Ausgraben in einem Siedlungshügel der Bronze-und Eisenzeit Makedoniens 1975-1979: Die Grabung und der Baubefund, Prähistorische Archäologie SüdostEuropa, 7, Volker Spiess, Berlin.

Hein, A., Tsolakidou, A., Iliopoulos, I., Mommsen, H., Buxeda i Garrigós, J., Montana, G., and Kilikoglou, V., 2002, Standardisation of elemental analytical techniques applied to provenance studies of archaeological ceramics: an interlaboratory calibration study, The Analyst, 127, 542-53.

Heurtley, W.A., 1939, Prehistoric Macedonia, Cambridge University Press, Cambridge.

Jones, R.E., 1986, Greek and Cypriot Pottery. A Review of the Scientific Studies, Fitch Laboratory Occasional Paper, 1, The British School at Athens, Athens.

Jones, R.E., Levi, S.T., and Vagnetti, L., 2002, Connections between the Aegean and Italy in the later Bronze Age: the ceramic evidence, in Modern Trends in Scientific 
Studies on Ancient Ceramics (eds. V. Kilikoglou, A. Hein and Y. Maniatis), 171-84, BAR International Series, S1011, Oxford.

Kessisoglou, M., Mirtsou-Karamoshou, E., Stratis, J., and Vassiliou, A., 1996, Study of pottery sherds from Mende, Chalkidiki, in Proceedings of the 2nd Greek Archaeometry Symposium (Thessaloniki 1993) (eds. I. Stratis, M. Vavelidis, K. Kotsakis, G. Tsokas and E. Tsoukala), 169-80, Hellenic Society of Archaeometry, Thessaloniki.

Kilikoglou, V., 1994, 'Scanning Electron Microscopy', in D.E. Wilson and P.M. Day, Ceramic Regionalism in Prepalatial Central Crete: The Mesara Imports at EMI to EMIIA Knossos, Annual of the British School at Athens, 89, 1-87.

Kingery, W.D., 1997, Operational principles of ceramic kilns, in The Prehistory and History of Ceramic Kilns (ed. P.M. Rice), 11-9, Ceramics and Civilization, VII, The American Ceramic Society, Westerville.

Kiriatzi, E., Andreou, S., Dimitriadis, S., and Kotsakis, K., 1997, Co-existing Traditions: Handmade and Wheelmade Pottery in Late Bronze Age Central Macedonia, in Texnh: craftsmen, craftswomen and craftsmanship in the Aegean Bronze Age II (eds. R. Laffineur and P.P. Betancourt), 361-68, Université de Liège, Histoire de l'art et archéologie de la Grèce antique - University of Texas at Austin, Program in Aegaen Scripts and Prehistory, Liege - Austin.

Leonard, A., Hughes, M., Middleton, A., and Schofield, L., 1993, The Making of Aegean Stirrup Jars: technique, tradition and trade, Annual of the British School at Athens, 88, 105-23.

Levi, S.T., 1999, Produzione e circolazione della ceramica nella Sibaritide protostorica I. Impasto e dolii, Grandi Contesti e Problemi della Protostoria Italiana, 1, All'Insegna del Giglio, Firenze.

Levi, S.T., Jones, R.E., Lazzarini, L., Sonnino, M., and Vagnetti, L., 1998, The Production and Distribution of Protohistoric Pottery in Italy: the Case of the Plain of Sybaris, in Proceedings of the XIII International Congress of Prehistoric and Prehistoric Sciences-Forli, Italia 8/14 September 1996, vol.4 ${ }^{\circ}$ - sections 10-12 (eds. R. de Marinis, A.M. Bietti Sestieri, R. Peroni and C. Peretto), 435-44, Abaco, Forlì. 
Maniatis, Y., and Tite, M.S., 1975, A Scanning Electron Examination of the Bloating of Fired Clays, Transactions and Journal of the British Ceramic Society, 74, 229-32.

Megaw, A.H.S., and Jones, R.E., 1983, Byzantine and allied pottery: a contribution by chemical analysis to problems of origin and distribution, Annual of the British School at Athens, 78, 235-63.

Mitchell, J.C., 1993, A petrographic study of Late Bronze Age Ceramics from the British School Excavations at Assiros, Macedonia, Fitch Laboratory, British School at Athens, Athens (unpublished internal report).

Mommsen, H., and Maran, J., 2000-2001, Production places of some Mycenaean Pictorial vessels - the contribution of chemical pottery analysis, Opuscula Atheniensia, 25-26, 95-106.

Mommsen, H., Beier, Th., Diehl, U., and Podzuweit, Ch., 1992, Provenance determination of Mycenaean sherds found in Tell el Amarna by neutron activation analysis, Journal of Archaeological Science, 19, 295-302.

Mommsen, H., Beier, T., Heimermann, D., Hein, A., Ittameier, D., and Podzuweit, Ch., 1994, Neutron Activation Analysis of Selected Sherds from Prophitis Ilias (Argolid, Greece): a Closed Late Helladic II Settlement Context, Journal of Archaeological Science, 21, 163-71.

Mommsen, H., Kreuser, A., Weber, J., and Podzuweit, Ch., 1989, Classification of Mycenaean pottery from Kastanas by Neutron Activation Analysis, in Archaeometry. Proceedings of the 25th International Symposium (ed. Y. Maniatis), 515-23, Elsevier, Amsterdam.

Mommsen, H., Lewandowski, E., Weber, J., and Podzuweit, Ch., 1988, Neutron Activation Analysis of Mycenaean Pottery from the Argolid: The Search for Reference Groups, in Proceedings of the 26th International Archaeometry Symposium (eds. R.M. Farquhar, R.G.V. Hancock and L.A. Pavlish), 165-71, The Archaeometry Laboratory, University of Toronto, Toronto. 
Noll, W., 1982, Mineralogie und Technik der Keramiken Altkretas, Neues Jahrbuch für Mineralogie Abhandlungen, 143, 150-99.

Pappa, M., 1990, Engatastasi tis epochis tou chalkou sto Polychrono Chalkididkis, Archaiologiko Ergo sti Makedonia kai Thraki, 4, 393-98 (in Greek).

Peroni, R. (ed.), 2000, Calabria prima dei Greci. Vent'anni di Scavi a Broglio di Trebisacce, Archeo, XVI, 8 (186), agosto, 57-83.

Peroni, R., and Trucco, F. (eds.), 1994, Enotri e Micenei nella Sibaritide, Istituto per la Storia e l'Archeologia della Magna Grecia, Taranto.

Peroni, R., and Vanzetti, A. (eds.), 1998, Broglio di Trebisacce 1990-1994. Elementi e problemi nuovi dalle recenti campagne di scavo, Rubbettino, Soveria Mannelli.

Tomlinson, J.E., 1997, Statistical evaluation of the Asaro-Perlman Neutron Activation data on Mycenaean pottery from the Peloponnese, Annual of the British School at Athens, 92, 139-64.

Tomlinson, J.E., 1998, A provenance investigation of Mycenaean pottery from Gla by NAA, Appendix, in Gla II (1981-1991 excavations) (S.E. Iakovidis), 205-8, Archaeological Society of Athens, 173, Athens.

Tomlinson, J.E., 2000, Statistical analysis of Neutron Activation data on Mycenaean pottery from Gla, Thebes, Eutresis, Kallithea and Tanagra in Boeotia, in Proceedings of the 3rd International Conference on Boeotian Studies (1996) (ed. V. Aravantinos), Annual of the Society of Boeotian Studies, 3:1, 253-63.

Vagnetti, L., 1999, Mycenaean Pottery in the Central Mediterranean: imports and local production in their context, in The Complex Past of Pottery. Production, circulation and consumption of Mycenaean and Greek Pottery (eds. J.P. Crielaard, V. Stissi and G.J. van Wijngaarden), 137-61, Gieben, Amsterdam.

Wardle, K.A., 1980, Excavations at Assiros, 1975-79, Annual of the British School at Athens, 75, 229-67. 
Wardle, K.A., 1993, Mycenaean trade and influence in Northern Greece, in Proceedings of the International Conference Wace and Blegen, pottery as evidence for trade in the Aegean Bronze Age 1939-1989 (eds. C. Zerner, P. Zerner and J. Winder), 117-41, Gieben, Amsterdam.

Whitbread, I.K., and Jones, R.E., forthcoming, A petrographic and chemical analysis of the Early Iron Age pottery at Torone, in The Early Iron Age Cemetery at Torone (J.K. Papadopoulos), Institute of Archaeology at University of California, Los Angeles. 
Figure captions

Table captions 


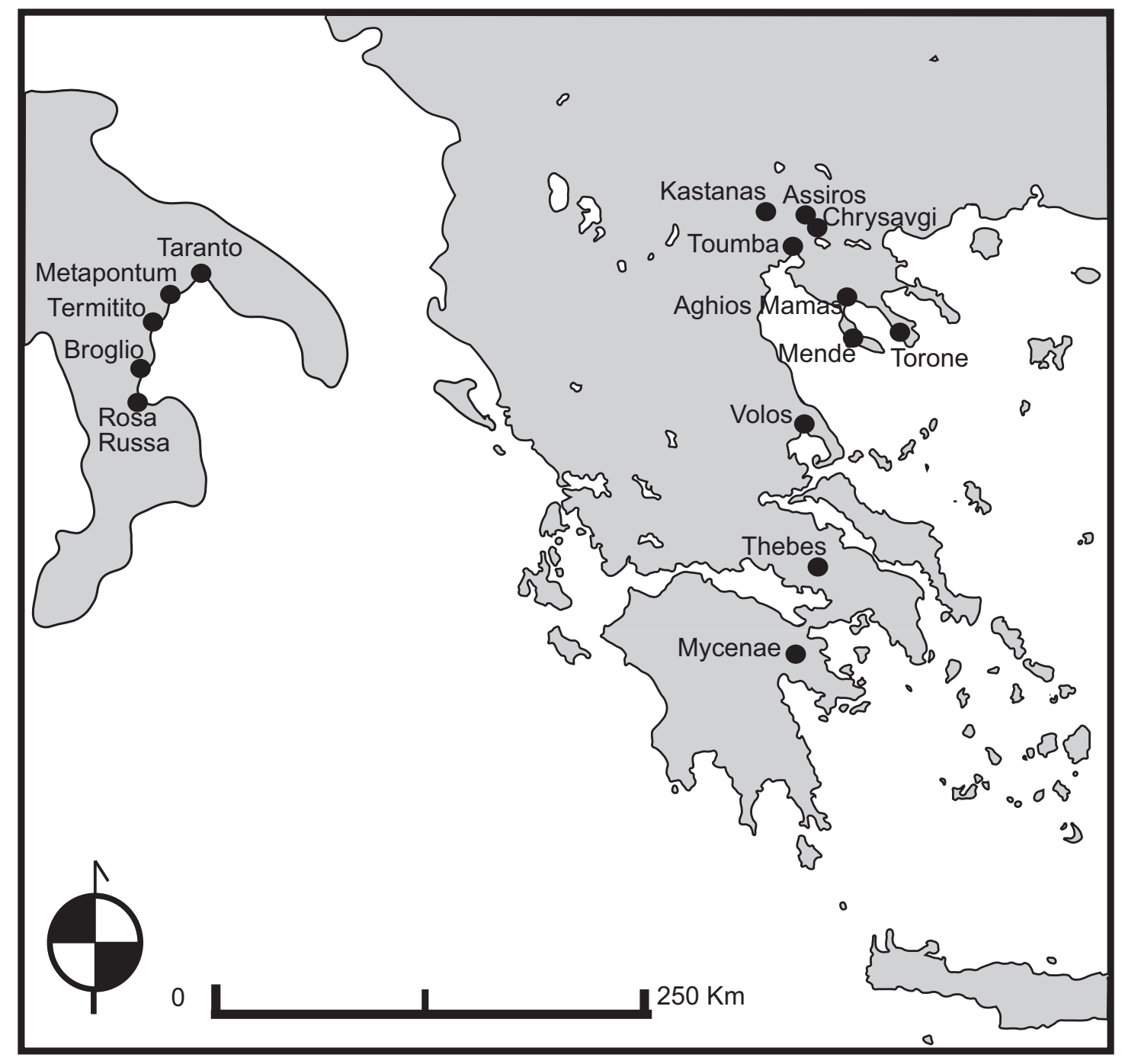

Figure 1. Map of Macedonia and Southern Italy 
$P_{\text {Local }}$

Imported

Provincial

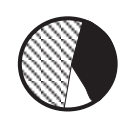

PHASE 9

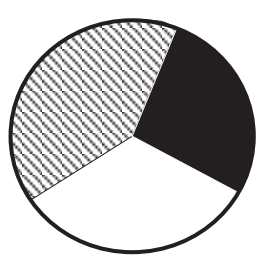

PHASE 8

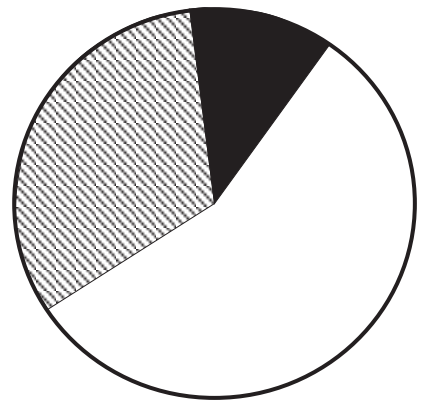

PHASE 7

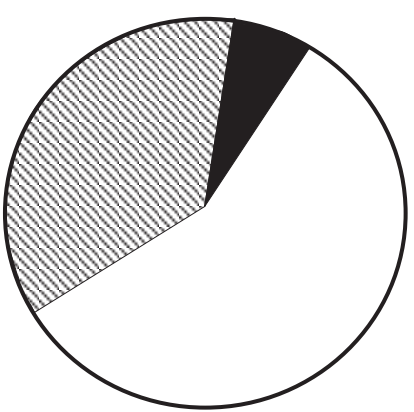

PHASE 6

Figure 2. Changes in frequency of the different classes of Mycenaean pottery at Assiros (Local (ALM), Provincial (APM) and Imported (AIM)), based on visual characteristics. Assisors phases 9, 8, 7 and 6 correspond to LH IIIA2, LH IIIB, LH IIIC and LH IIIC respectively. The area of each circle is proportional to the relative frequency of Mycenaean sherds in each phase (sherds per $100 \mathrm{~m}^{3}$ of deposit). After Wardle 1993, Figure 5 


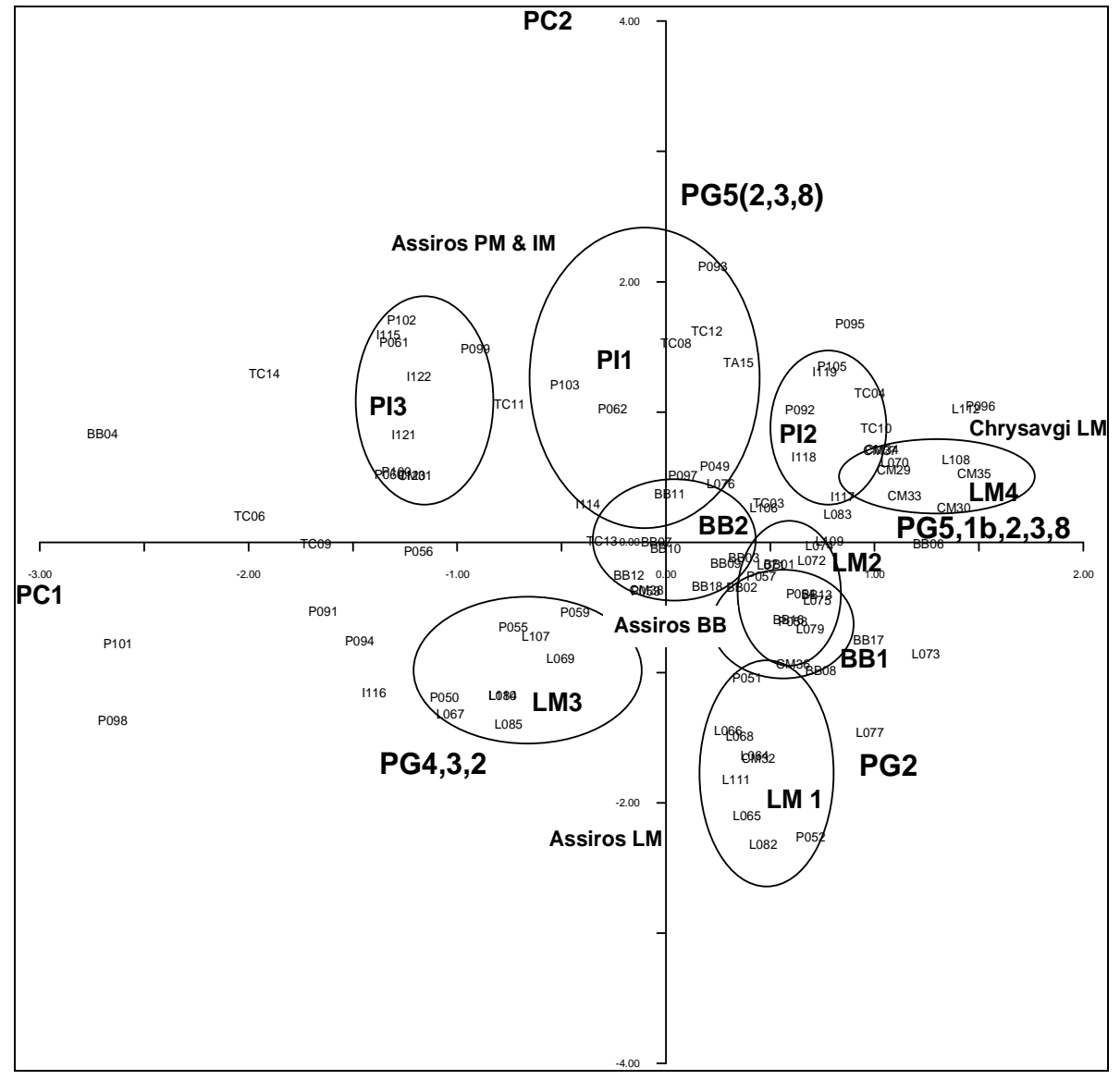

Figure 3. PCA of the Macedonia INAA data. Plot of PC1 vs. PC2, explaining 62\% and $11 \%$ respectively of the total variance. All chemical groups, except LM5, are shown; their limits are not probabilistic ellipsoids. The petrographic groups (PG) are superimposed on the plot. For the purpose of legibility, samples are labelled in abbreviated form: L (for ALM), P (for APM), I (for AIM), BB (for ABB), TC (for TMY), TA (for TMA), and CM (for CLM) 


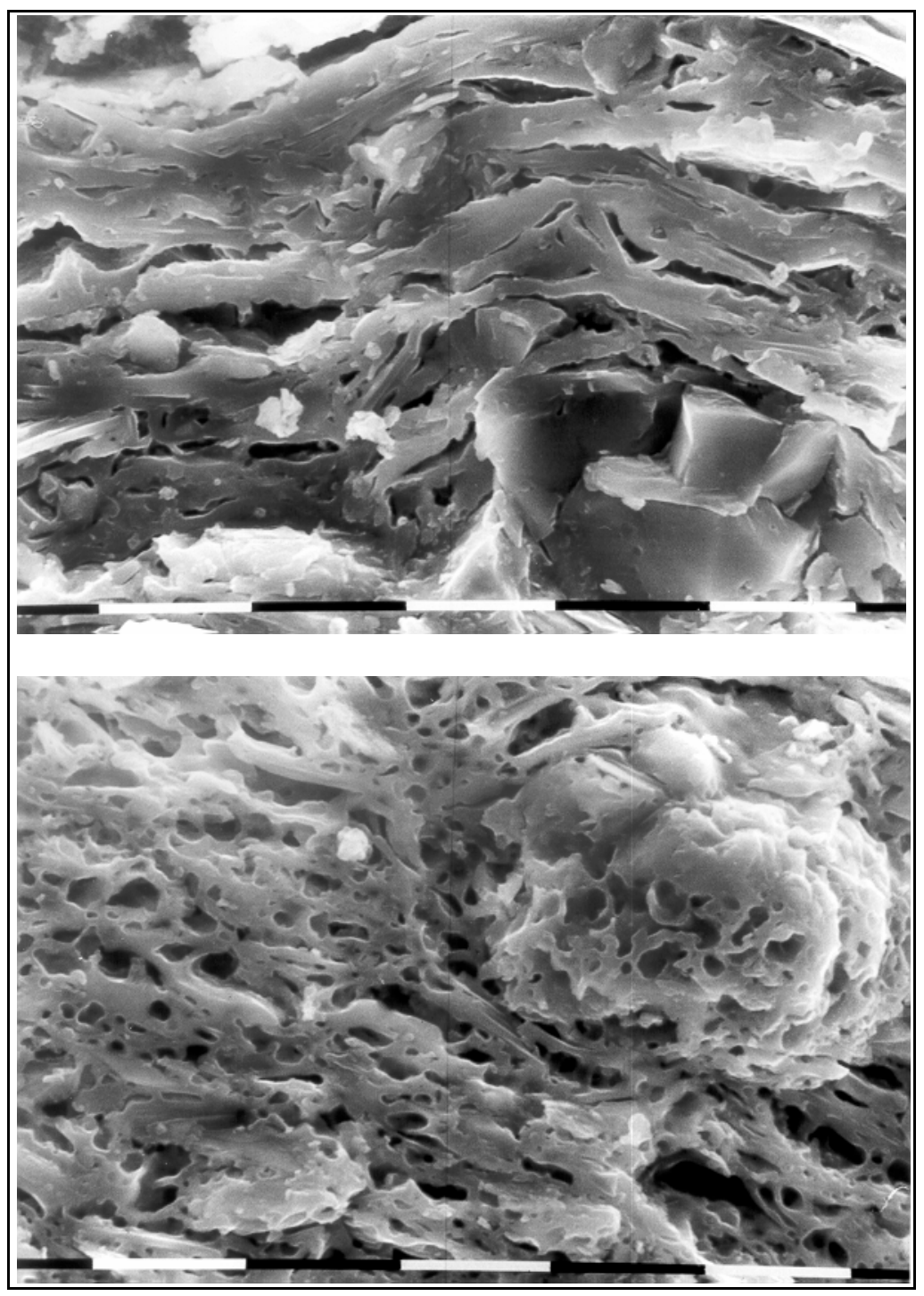

Figure 4. SEM microphotographs of ALM111 (in group LM1) showing (top) typical $\mathrm{Vc}$ (continuous vitrification) microstructure in the areas close to the external and internal surfaces, and (bottom) the microstructure in the grey core with high concentration of fine bloating pores. Magnification $2.02 \times 10^{3}$. The bar indicates 10 $\mu \mathrm{m}$ 


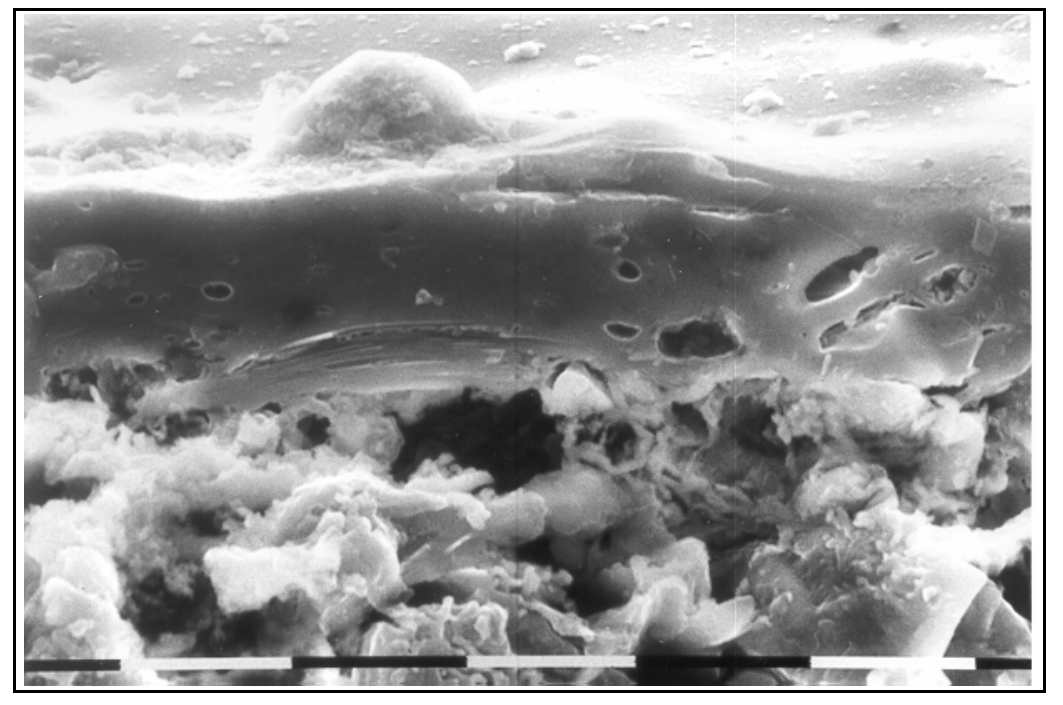

Figure 5. SEM microphotograph of Assiros Provincial Mycenaean sample 99 (group PI3) with black decoration of good quality. Magnification $2.02 \times 10^{3}$. The bar indicates $10 \mu \mathrm{m}$ 


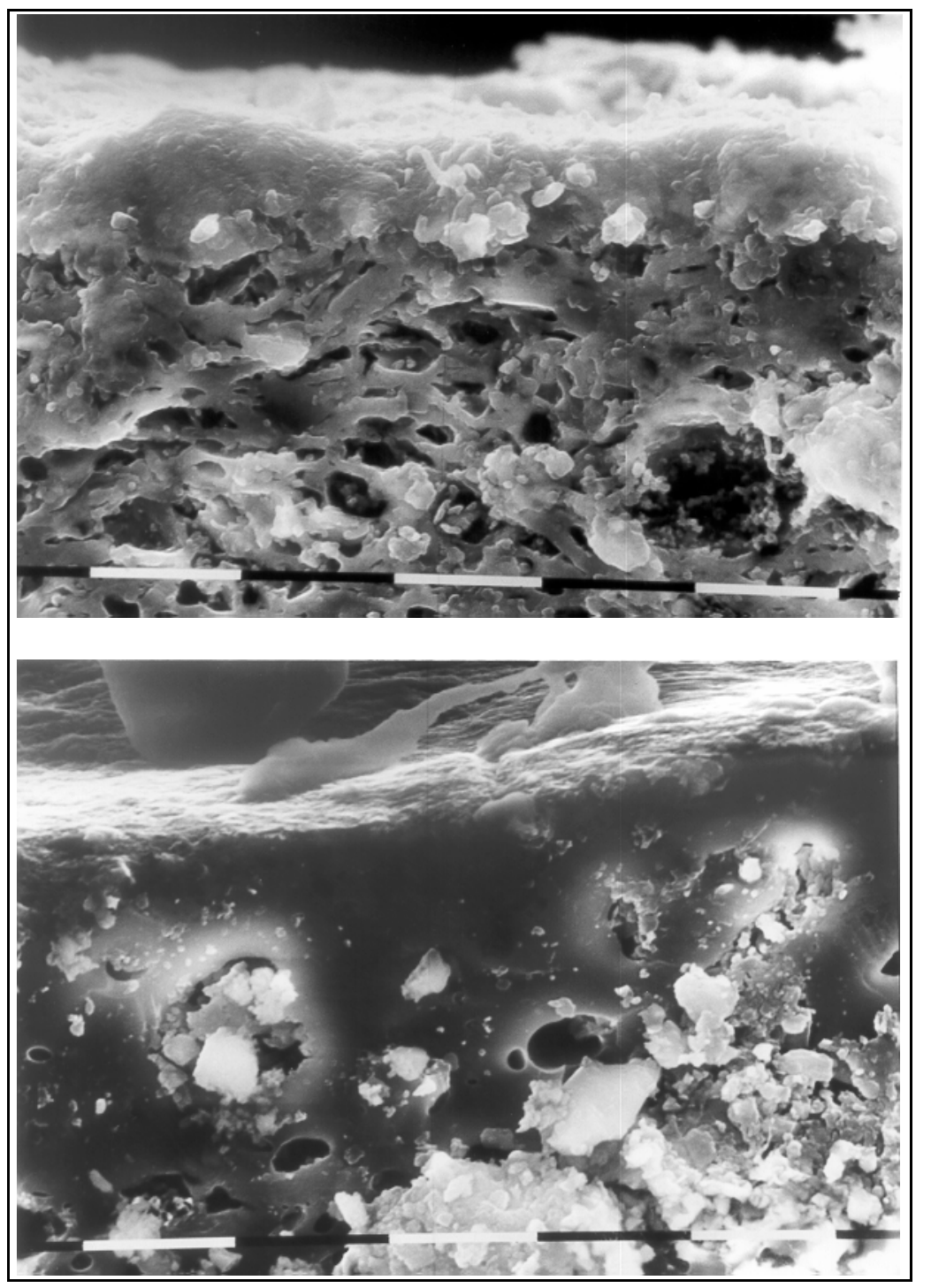

Figure 6. SEM microphotographs of (top) BTA68 (Mycenaean decorated) showing the white decoration and matrix of a Vc (continuous vitrification) microstructure, and (bottom) BTG28 (Grey ware) showing the black decoration and Vc+/TV (continuous vitrification plus/total vitrification) matrix. Magnification $2.02 \times 10^{3}$. The bar indicates $10 \mu \mathrm{m}$ 
Table 1 The material analysed from Macedonia and southern Italy, according to site and technique. In brackets, abbreviations of archaeological categories used in the text

\begin{tabular}{|c|c|c|c|c|}
\hline Site and Archaeological Type & $\overline{N A A}$ & SEM & $X R D$ & $P E$ \\
\hline \multicolumn{5}{|l|}{ MACEDONIA } \\
\hline \multicolumn{5}{|l|}{ Assiros } \\
\hline Brown Burnished (ABB) & 15 & & 7 & 28 \\
\hline Local Mycenaean (ALM) & 27 & 9 & 9 & 22 \\
\hline Provincial Mycenaean (APM) & 29 & 17 & 12 & 5 \\
\hline Imported Mycenaean (AIM) & 9 & 9 & 3 & \\
\hline Total & 80 & 35 & 31 & 55 \\
\hline \multicolumn{5}{|l|}{ Chrysavgi } \\
\hline Local Mycenaean (CLM) & 10 & & 3 & 10 \\
\hline \multicolumn{5}{|l|}{ Aghios Mamas } \\
\hline Mycenaean type (AM) & & & & 10 \\
\hline \multicolumn{5}{|l|}{ Thessaloniki } \\
\hline Mycenaean type (TMY) & 14 & 7 & 7 & \\
\hline Matt painted (TMA) & 2 & 2 & & \\
\hline Total & 16 & 9 & 7 & \\
\hline \multicolumn{5}{|l|}{ ARGOLID } \\
\hline \multicolumn{5}{|l|}{ Mycenae } \\
\hline Decorated LH IIIA-B & & 5 & & \\
\hline \multicolumn{5}{|l|}{ SOUTHERN ITALY } \\
\hline \multicolumn{5}{|l|}{ Broglio di Trebisacce } \\
\hline Aegean/Mycenaean type (BTA) & 6 & 13 & & \\
\hline Grey ware (BTG) & 6 & 9 & & \\
\hline Figulina (BTF) & 6 & 9 & & \\
\hline Dolia (BTD) & 6 & 10 & & \\
\hline Impasto (BTI) & 5 & 9 & & \\
\hline Miscellany (BT) & & 3 & 3 & \\
\hline Total & 29 & 53 & 3 & \\
\hline \multicolumn{5}{|l|}{ Rosa Russa } \\
\hline Impasto (BTI) & 1 & 4 & & \\
\hline
\end{tabular}


Table 2. Macedonia: correspondence between chemical groups along the top row and the archaeologically-derived classes in the left-hand column (see abbreviations in Table 1). Clay type: $\mathrm{C}$, calcareous; LC, low calcareous. FF = fast firing

\begin{tabular}{|c|c|c|c|c|c|c|c|c|c|c|c|c|}
\hline & $L M 1$ & $L M 2$ & $L M 3$ & LM4 & LM5 & $P I 1$ & $P I 2$ & $P I 3$ & BB1 & $B B 2$ & Unassigned & Total \\
\hline ALM & 6 & 4 & 6 & 2 & 1 & & & & & & 8 & 27 \\
\hline APM & 2 & 3 & 2 & & & 3 & 3 & 6 & & & 10 & 29 \\
\hline AIM & & & & & & 1 & 3 & 4 & & & 1 & 9 \\
\hline CLM & 1 & 1 & & 6 & & & & 1 & & & 1 & 10 \\
\hline TMY & & & & & 4 & 2 & 2 & 2 & & & 4 & 14 \\
\hline TMA & & & & & & 1 & & & & & 1 & 2 \\
\hline ABB & & & & & & & & & 4 & 7 & 4 & 15 \\
\hline Total & 9 & 8 & 8 & 8 & 5 & 7 & 8 & 13 & 4 & 7 & 29 & 106 \\
\hline & & & & & & & & & & & & \\
\hline $\begin{array}{l}\text { Clay } \\
\text { type }\end{array}$ & LC & LC & LC & LC & $\mathrm{C}$ & $\mathrm{C}$ & $\mathrm{C}$ & $\mathrm{C}$ & $\mathrm{LC}$ & LC & & \\
\hline $\begin{array}{l}\text { Firing } \\
\text { temp. }{ }^{\circ} \mathrm{C}\end{array}$ & $\begin{array}{c}800- \\
900 \\
\text { FF }\end{array}$ & $\begin{array}{l}<800 \\
(\mathrm{FF})\end{array}$ & $\begin{array}{l}800- \\
900 \\
\text { FF }\end{array}$ & \begin{tabular}{|c|}
$<800$ \\
$(850 ?)$
\end{tabular} & $\begin{array}{c}<800 \\
(850 ?)\end{array}$ & $\begin{array}{l}850- \\
1050\end{array}$ & $\begin{array}{l}850- \\
1050\end{array}$ & $\begin{array}{l}850- \\
1050\end{array}$ & $<800$ & $<800$ & & \\
\hline
\end{tabular}


Table 3. Means (m), in ppm (except $\mathrm{Ca}, \mathrm{Na}$ and $\mathrm{Fe}$ in \%), and standard deviation in \% (\%sd) of the chemical composition groups from Assiros, Chrysavgi and Toumba Thessaloniki, and $A 1$ from Southern Italy

\begin{tabular}{|c|c|c|c|c|c|c|c|c|c|c|c|c|c|c|c|c|c|c|c|c|c|c|}
\hline & $\mathbf{L M 1}$ & =9) & & & $L \Lambda$ & & $\boldsymbol{L} \Lambda$ & & $\boldsymbol{L} 1$ & & $(\mathrm{n}=$ & & $(n=$ & & $(n=$ & 13) & $B 1$ & & $\boldsymbol{B}$ & & $(n=$ & \\
\hline & $\mathrm{m}$ & $\%$ sd & $\mathrm{m}$ & $\%$ sd & $\mathrm{m}$ & $\%$ sd & $\mathrm{m}$ & $\%$ sd & $\mathrm{m}$ & $\%$ sd & $\mathrm{m}$ & $\%$ sd & $\mathrm{m}$ & $\%$ sd & $\mathrm{m}$ & $\%$ sd & $\mathrm{m}$ & $\%$ sd & $\mathrm{m}$ & $\% \mathrm{sd}$ & $\mathrm{m}$ & $\%$ sd \\
\hline Sm & 7.81 & 11.9 & 7.38 & 6.6 & 5.85 & 6.5 & 7.56 & 10.2 & 4.55 & 7.5 & 6.12 & 13.1 & 6.66 & 4.5 & 5.30 & 10.2 & 9.48 & 6.7 & 6.83 & 6.7 & 6.54 & 7.9 \\
\hline Lu & 0.44 & 13.6 & 0.41 & 9.8 & 0.37 & 8.1 & 0.48 & 12.5 & 0.30 & 6.7 & 0.39 & 15.4 & 0.39 & 5.1 & 0.35 & 8.6 & 0.52 & 9.6 & 0.41 & 9.8 & 0.36 & 11.1 \\
\hline $\mathbf{U}$ & 5.1 & 31.4 & 4.4 & 22.7 & 2.2 & 13.6 & 3.9 & 28.2 & $1.7 *$ & 29.4 & 2.7 & 18.5 & 2.7 & 14.8 & 2.3 & 26.1 & 4.6 & 26.1 & 2.9 & 13.8 & 2.9 & 20.7 \\
\hline $\mathbf{Y b}$ & 3.77 & 11.14 & 3.39 & 5.3 & 3.20 & 6.2 & 4.03 & 7.2 & 2.61 & 11.5 & 3.28 & 9.4 & 3.29 & 5.2 & 3.00 & 5.7 & 4.06 & 7.6 & 3.56 & 9.0 & 2.88 & 9.4 \\
\hline As & 22.5 & 36.4 & 13.0 & 55.4 & 17.7 & 37.3 & 10.7 & 17.8 & 13.0 & 81.5 & 7.2 & 45.8 & $6.9^{*}$ & 82.6 & 11.0 & 129.1 & 8.9 & 55.1 & 21.1 & 92.9 & 6.1 & 31.1 \\
\hline Sb & 0.7 & 22.8 & 0.6 & 33.3 & $1.1^{*}$ & 18.2 & 0.7 & 14.3 & 1.2 & 25.0 & 0.7 & 14.3 & $0.2 *$ & 50.0 & $0.5^{*}$ & 20.0 & $0.5^{*}$ & 12.0 & $0.7^{*}$ & 57.1 & $0.7^{*}$ & 14.3 \\
\hline Ca \% & $\mathrm{nd}^{*}$ & nd & $2.58 *$ & 26.0 & $4.15^{*}$ & 27.2 & $4.20 *$ & nd & $4.31 *$ & 15.1 & $4.11^{*}$ & 18.5 & 4.57 & 26.0 & $6.10^{*}$ & 23.1 & $\mathrm{nd}^{*}$ & nd & $1.85^{*}$ & 21.6 & $5.37 *$ & 24.2 \\
\hline $\mathrm{Na} \%$ & 1.25 & 14.4 & 1.50 & 9.3 & 1.11 & 5.4 & 1.32 & 22.0 & 1.79 & 6.1 & 1.68 & 14.9 & 1.88 & 10.6 & 1.13 & 25.7 & 1.18 & 6.8 & 1.29 & 10.8 & 0.82 & 14.6 \\
\hline La & 47.4 & 6.4 & 40.2 & 7.0 & 31.5 & 4.8 & 44.1 & 11.6 & 24.1 & 3.7 & 33.3 & 5.4 & 34.3 & 4.7 & 29.1 & 7.2 & 53.1 & 7.2 & 36.4 & 7.1 & 36.9 & 7.8 \\
\hline $\mathrm{Ce}$ & 113.5 & 6.6 & 93.7 & 9.1 & 76.4 & 5.6 & 100.4 & 11.9 & 60.2 & 3.0 & 79.6 & 6.5 & 83.6 & 5.3 & 73.4 & 7.9 & 112.1 & 11.5 & 85.3 & 11.6 & 82.0 & 7.2 \\
\hline Th & 19.7 & 7.1 & 15.6 & 10.9 & 10.9 & 7.3 & 17.9 & 17.9 & 10.0 & 3.0 & 13.4 & 4.5 & 13.3 & 4.5 & 11.9 & 9.2 & 19.3 & 7.2 & 12.6 & 7.9 & 13.8 & 10.9 \\
\hline $\mathrm{Cr}$ & 107.4 & 5.9 & 104.8 & 14.2 & 136.6 & 4.7 & 91.1 & 15.0 & 284.6 & 6.6 & 196.7 & 13.5 & 94.4 & 10.9 & 416.8 & 12.8 & 130.5 & 4.1 & 121.8 & 16.1 & 85.6 & 13.4 \\
\hline Hf & 2.68 & 20.5 & 4.74 & 12.9 & 4.72 & 13.1 & 7.81 & 17.1 & 4.23 & 12.1 & 5.53 & 15.9 & 5.85 & 10.1 & 3.85 & 9.1 & 6.29 & 9.5 & 6.85 & 10.1 & 4.89 & 10.0 \\
\hline Cs & 7.65 & 6.3 & 6.46 & 9.6 & 5.42 & 9.8 & 6.92 & 9.4 & 48.66 & 42.8 & 6.54 & 8.9 & 4.20 & 17.4 & 6.04 & 15.6 & 8.35 & 5.4 & 4.49 & 12.9 & 7.47 & 16.5 \\
\hline Tb & $1.0^{*}$ & 20 & $0.9^{*}$ & 22.2 & $0.5^{*}$ & 60.0 & 1.0 & 20.0 & 0.5 & 60.0 & 0.8 & 50.0 & 0.8 & 25.0 & $0.6^{*}$ & 33.3 & $1.0^{*}$ & 30.0 & $0.8^{*}$ & 62.5 & $0.7^{*}$ & 42.9 \\
\hline Sc & 19.51 & 3.6 & 17.34 & 6.6 & 19.58 & 4.4 & 15.72 & 9.1 & 20.47 & 3.7 & 16.20 & 9.6 & 13.80 & 6.2 & 19.01 & 6.6 & 20.84 & 4.7 & 18.01 & 6.4 & 13.79 & 6.7 \\
\hline $\mathbf{R b}$ & 187 & 9.1 & 166 & 12.6 & 120 & 17.5 & 161 & 7.4 & 144 & 36.8 & 121 & 17.3 & 161 & 11.2 & 133 & 21.0 & 187 & 13.9 & 129 & 24.0 & 136 & 16.9 \\
\hline $\mathrm{Fe} \%$ & 5.76 & 5.0 & 4.79 & 9.6 & 4.99 & 4.4 & 4.38 & 10.5 & 4.69 & 7.9 & 4.21 & 8.1 & 4.25 & 9.2 & 5.65 & 6.4 & 5.48 & 5.6 & 4.79 & 5.4 & 4.04 & 7.4 \\
\hline Ta & 1.6 & 18.7 & 1.6 & 12.5 & 1.0 & 30.0 & 1.7 & 11.8 & 1.0 & 20.0 & 1.3 & 15.4 & 1.1 & 18.2 & 1.2 & 16.7 & 1.9 & 10.5 & 1.4 & 21.4 & 1.3 & 30.8 \\
\hline Co & 23.63 & 8.42 & 19.70 & 17.0 & 25.64 & 6.9 & 17.31 & 8.3 & 29.18 & 13.8 & 21.88 & 11.4 & 17.74 & 9.0 & 42.00 & 10.2 & 21.94 & 8.4 & 21.09 & 19.1 & 13.79 & 10.7 \\
\hline Eu & 1.66 & 15.7 & 1.60 & 11.9 & 1.35 & 11.1 & 1.50 & 7.3 & 1.02 & 10.8 & 1.31 & 15.3 & 1.44 & 15.3 & 1.21 & 14.9 & 1.93 & 16.6 & 1.58 & 15.8 & 1.23 & 8.1 \\
\hline
\end{tabular}

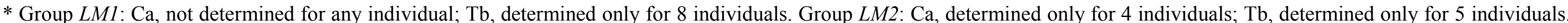

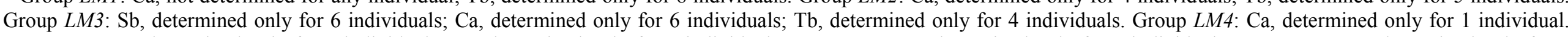

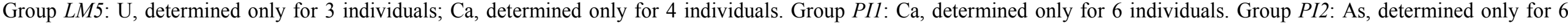

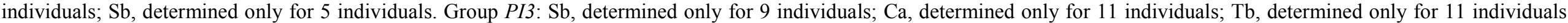

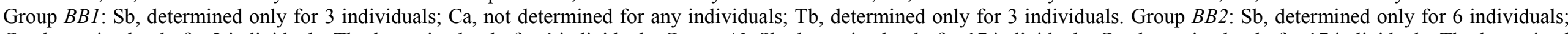

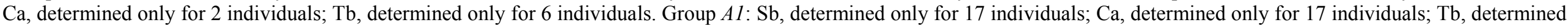
only for 17 individuals. $(\mathrm{m}=$ mean; $\% \mathrm{sd}=$ standard deviation in $\%$; $\mathrm{nd}=$ non determined $)$ 
Table 4. Petrographic classification (see abbreviations in Table 1)

\begin{tabular}{|c|c|c|}
\hline $\begin{array}{l}\text { Petrographic } \\
\text { Group }\end{array}$ & $\begin{array}{c}\text { Archaeological } \\
\text { Class and number } \\
\text { of individuals }\end{array}$ & Characteristics \\
\hline $1 \mathrm{a}$ & ABB - 19 & $\begin{array}{l}\text { Variable colour; dark core; micaceous clay with much } \\
\text { metamorphic quartz; biotite and muscovite; occasional } \\
\text { rounded, weathered quartz-mica schist }\end{array}$ \\
\hline $1 b$ & $\begin{array}{l}\text { ABB - } 4 \\
\text { CLM - } 1\end{array}$ & Similar to 1a but more schistose. Schist is biotite \\
\hline $1 \mathrm{c}$ & ABB - 3 & Similar to 1a but some coarse, altered calcareous material \\
\hline 2 & $\begin{array}{l}\text { CLM - } 3 \\
\text { ALM - } 8 \\
\text { APM - } 4\end{array}$ & $\begin{array}{l}\text { Similar variation in colour and grey core as Group 1. Small- } \\
\text { size quartz and mica; occasional altered calcareous material }\end{array}$ \\
\hline 3 & $\begin{array}{l}\text { CLM - } 1 \\
\text { AM - } 9 \\
\text { ALM - } 1 \\
\text { APM - } 4\end{array}$ & $\begin{array}{l}\text { Similar to Groups } 1 \text { and } 2 \text {, but no common alignment of } \\
\text { inclusions and less micaceous material }\end{array}$ \\
\hline 4 & $\begin{array}{l}\text { ALM - } 8 \\
\text { APM - } 4\end{array}$ & $\begin{array}{l}\text { Fine grained inclusions of quartz, mica, schist and calcareous } \\
\text { material }\end{array}$ \\
\hline 5 & $\begin{array}{l}\text { ALM - } 2 \\
\text { APM - } 1 \\
\text { AM - 1 } \\
\text { CLM - } 3\end{array}$ & $\begin{array}{l}\text { Inclusions similar to previous groups, but notable presence of } \\
\text { polycrystalline quartz with plagioclase (microcline) feldspar }\end{array}$ \\
\hline 6 & APM - 6 & Rounded, unaligned quartz and mica \\
\hline 7 & ALM - 3 & Fine-grained group \\
\hline 8 & $\begin{array}{l}\text { APM - } 2 \\
\text { CLM - } 1\end{array}$ & $\begin{array}{l}\text { Fine-grained group dominated by micaceous and mica-schist } \\
\text { inclusions }\end{array}$ \\
\hline Singletons & $\begin{array}{c}\text { ABB - } 1 \\
\text { CLM - } 1\end{array}$ & \\
\hline
\end{tabular}


Table 5. Southern Italy: correspondence between chemical group, type of pottery and technological parameters. Ca, clay type: $\mathrm{C}$, calcareous; LC, low calcareous. Atmosphere: $\mathrm{O}$, oxidising; $\mathrm{R}$, reducing; $\mathrm{RO} / \mathrm{O}$, reducing-oxidising/ oxidising. * presence of a darker core. $\mathrm{NV}$, no vitrification; IV, initial vitrification; $\mathrm{Vc}$, extensive vitrification; $\mathrm{TV}$, total vitrification

\begin{tabular}{|c|c|c|c|c|c|}
\hline Type & Samples & $C a$ & Atmosphere & Decoration & Firing temperature ${ }^{\circ} \mathrm{C}$ \\
\hline \multicolumn{6}{|l|}{ Group A1 } \\
\hline \multirow{4}{*}{ Aegean } & BTA69 & $\bar{C}$ & $\mathrm{O}$ & & $\mathrm{NV}<800$ \\
\hline & BTA5 & $\mathrm{C}$ & $\mathrm{RO} / \mathrm{O}$ & Red & Vc 850-1050 \\
\hline & BTA1 & $\mathrm{C}$ & $\mathrm{RO} / \mathrm{O}$ & Red & $\mathrm{Vc} / \mathrm{Vc}+850-1080$ \\
\hline & BTA4 & $\mathrm{C}$ & $\mathrm{RO} / \mathrm{O}^{*}$ & Black & TV $>1080$ \\
\hline \multirow{3}{*}{ Figulina } & BTF42 & $\mathrm{C}$ & $\mathrm{O}$ & & $\mathrm{NV}<800$ \\
\hline & BTF41 & $\mathrm{C}$ & $\mathrm{RO} / \mathrm{O}$ & & IV/Vc- $750-850$ \\
\hline & BTF21 & $\mathrm{C}$ & $\mathrm{O}$ & & $\mathrm{Vc} / \mathrm{Vc}+850-1080$ \\
\hline \multirow{5}{*}{ Grey Ware } & BTG22 & $\mathrm{C}$ & $\mathrm{R}^{*}$ & & $\mathrm{NV}<800$ \\
\hline & BTG71 & $\mathrm{C}$ & $\mathrm{R}$ & & $\mathrm{Vc}-/ \mathrm{Vc} 800-1050$ \\
\hline & BTG26 & $\mathrm{C}$ & $\mathrm{R}^{*}$ & & Vc $850-1050$ \\
\hline & BTG24, 67 & $\mathrm{C}$ & $\mathrm{R}$ & & $\mathrm{Vc} / \mathrm{Vc}+850-1080$ \\
\hline & BTG25 & $\mathrm{C}$ & $\mathrm{R}$ & & $\mathrm{Vc}+1050-1080$ \\
\hline \multirow{2}{*}{ Dolia } & BTD34, 36 & $\mathrm{C}$ & $\mathrm{R} ; \mathrm{O}$ & & NV/IV $<850$ \\
\hline & BTD30 & $\mathrm{C}$ & $\mathrm{O}$ & & Vc 850-1050 \\
\hline Impasto & BTI50, 66 & $\mathrm{LC}$ & $\mathrm{R} ; \mathrm{RO} / \mathrm{O}$ & & $\mathrm{NV}<750$ \\
\hline \multicolumn{6}{|l|}{ Group A2 } \\
\hline \multirow{2}{*}{ Figulina } & BTF39 & $\mathrm{C}$ & $\mathrm{O}$ & Red & $\mathrm{NV} / \mathrm{IV}<850$ \\
\hline & BTF37 & $\mathrm{C}$ & $\mathrm{R}$ & Black & $\mathrm{Vc} / \mathrm{Vc}+850-1080$ \\
\hline Dolia & BTD63 & $\mathrm{C}$ & $\mathrm{O}$ & & Vc-/Vc 800-1050 \\
\hline \multicolumn{6}{|l|}{ Group B } \\
\hline \multirow{2}{*}{ Dolia } & BTD35 & $\mathrm{LC}$ & $\mathrm{RO} / \mathrm{O}$ & & V 800-900 \\
\hline & BTD62 & $\mathrm{C}$ & $\mathrm{RO} / \mathrm{O}$ & & Vc $850-1050$ \\
\hline \multicolumn{6}{|l|}{ Group C } \\
\hline Impasto & BTI55, 65, 70 & $\mathrm{LC}$ & $\mathrm{RO} / \mathrm{O}$ & & $\mathrm{NV}<750$ \\
\hline \multicolumn{6}{|l|}{ Outliers } \\
\hline Aegean & BTA3, 68 & $\mathrm{C}$ & $\mathrm{R} ; \mathrm{O}$ & Black & Vc 850-1050 \\
\hline Figulina & BTF43 & $\mathrm{C}$ & $\mathrm{O}$ & & $\mathrm{NV} / \mathrm{IV}<850$ \\
\hline Impasto & BTI59 & $\mathrm{LC}$ & $\mathrm{RO} / \mathrm{O}$ & & $\mathrm{NV}<750$ \\
\hline \multicolumn{6}{|c|}{ Not analysed by NAA } \\
\hline \multirow{3}{*}{ Aegean } & BTA7, 8,11 & $\mathrm{C}$ & $\mathrm{RO} / \mathrm{O} ; \mathrm{O}$ & Red & $\mathrm{NV}<800$ \\
\hline & BTA6, 16 & $\mathrm{C}$ & $\mathrm{R} ; \mathrm{RO} / \mathrm{O}$ & & Vc 850-1050 \\
\hline & BTA2, 9 & $\mathrm{C}$ & $\mathrm{RO} / \mathrm{O}$ & Red; Black & $\mathrm{Vc} / \mathrm{Vc}+850-1080$ \\
\hline \multirow{3}{*}{ Figulina } & $\begin{array}{l}\text { BTF47 } \\
\end{array}$ & $\mathrm{C}$ & $\mathrm{RO} / \mathrm{O}$ & & NV/IV $<850$ \\
\hline & BTF48 & $\mathrm{C}$ & $\mathrm{O}$ & & Vc-/Vc 800-1050 \\
\hline & BTF38 & $\mathrm{C}$ & $\mathrm{RO} / \mathrm{O}$ & Black & $\mathrm{Vc} / \mathrm{Vc}+850-1080$ \\
\hline \multirow{2}{*}{ Grey Ware } & BTG23 & $\mathrm{C}$ & $\mathrm{R}^{*}$ & & $\mathrm{NV} / \mathrm{IV}<850$ \\
\hline & BTG27, 28 & $\mathrm{C}$ & $\mathrm{R}^{*} ; \mathrm{R}$ & Black & $\mathrm{Vc}+/ \mathrm{TV}>1050$ \\
\hline Dolia & $\begin{array}{l}\text { BTD29, 31, 32, } \\
33\end{array}$ & $\mathrm{C}$ & $\mathrm{O}$ & & Vc 850-1050 \\
\hline \multirow[t]{2}{*}{ Impasto } & $\begin{array}{l}\text { BTI49, 51, 54, } \\
60,57,61\end{array}$ & LC & $\mathrm{RO} / \mathrm{O} ; \mathrm{R}$ & & $\mathrm{NV}<750$ \\
\hline & BTI56 & $\mathrm{C}$ & $\mathrm{RO} / \mathrm{O}$ & & $\mathrm{NV}<750$ \\
\hline
\end{tabular}

